\title{
Tim O’Brien's “Bad” Vietnam War: Going after Cacciato \& Its Historical Perspective
}

\author{
Ramtin Noor-Tehrani (Noor) Mahini \\ Acalanes High School, Lafayette, California, USA \\ Erin Barth \\ Acalanes High School, Lafayette, California, USA \\ Jed Morrow \\ Acalanes High School, Lafayette, California, USA
}

\begin{abstract}
Being the only Vietnam War author on the English curriculum for American middle and high schools, Tim O'Brien skillfully mixes his real wartime experience with fiction in his various bestsellers and awarded novels. All O'Brien's Vietnam War stories are always "bad," meaning that the war contains mostly sad and horrific experience for American soldiers and Vietnamese civilians. A closer look at O'Brien's war stories reveals that he indeed touches upon almost all issues the American GIs encountered during this war; nevertheless, not all online literary analysis websites and peer-reviewed authors can identify or call them all out. To assist middle and high school readers in understanding the meaning behind Tim O'Brien's Vietnam War stories, the war details in Going After Cacciato and its historical perspective are discussed in this article. The war-related issues that $O$ 'Brien touched upon in this novel are: lack of purpose, the lower standards of the American troops (McNamara's morons), desertion, lack of courage, friendly fire, fragging their own officers, and contemptuous attitude toward the Vietnamese, the very people they came to help and protect.
\end{abstract}

Index Terms-Tim O'Brien, Vietnam War, fragging, McNamara's Folly, McNamara's Morons, McNamara's Boys, gooks, dinks, desertion, friendly fire, Guerrilla War

\section{INTRODUCTION}

Of nearly 30,000 published literature on the Vietnam War, only Tim O'Brien's work has been studied by American middle and high school students on their English curriculum (Walzer, 2010). As one of the most prominent contemporary American writers, Tim O'Brien employs both fiction and his real wartime experience in his various bestsellers and awarded novels. Sent to Vietnam in 1969, when the Nixon administration already started the "Vietnamization" process, O’Brien observed that, "By 1969, nobody ever talked about winning... we had been reading enough headlines to absorb the hopelessness of the war" (Ackerman, 2017). Although O'Brien does not think that he is a Vietnam War writer, he recognizes that three of his books "have a lot of Vietnam in them... In the Lake of the Woods occurs after Vietnam and living with the consequences of history and misdeed and horror. Cacciato is a fabulist running-away-from-the war-story. The Things They Carried is a book largely about storytelling and issues about truth" (Hicks, 2005). O'Brien may not know that collectively, all his writing about the important issues the American troops face during the "bad" Vietnam War period gives us a complete list of possible reasons why the most powerful nation on earth - the United States (US) of America - lost the war in Vietnam - a poor and war ravaged Third World country (Mahini et al., 2018a). Most online literary analysis websites (e.g., cliffsnotes.com, litcharts.com, or sparknotes.com) and peer-reviewed publications on Tim O'Brien's novels (e.g., Slay, Jr., 1999; Womack, 2013) focus on literary devices and a few narrow war aspects of his books. Even the most comprehensive reviews of Tim O'Brien's work (Heberle, 2001; Vernon and Calloway, 2010) do not address all these war issues within their historical context. This article specifically focuses on Going After Cacciato (O'Brien, 1978) and discusses the historical perspective of the war-related issues presented by O'Brien in this novel. Its primary purpose is to assist middle and high school readers in understanding the meaning behind Tim O'Brien's writing about the Vietnam War, know its entire big picture, and determine which American soldiers' actions - as described by O'Brien - may not be morally or legally correct under the US law of war.

\section{O'BRIEN's “BAD” VIETNAM WAR IN GOING AFTER CACCIATO}

Information about the author and a detailed discussion about the "good" and the "bad" Vietnam War periods have been presented in "Tim O'Brien's 'Bad' Vietnam War: The Things They Carried and Its Historical Perspective" (Mahini et al., 2018a). In Going after Cacciato - a "running-away-from-the war-story," O'Brien skillfully scrambles the chronology of the events throughout the 46 chapters of the book to describe the wrenching, traumatic war stories experienced by a young and inexperienced soldier named Paul Berlin. Staying up all night to watch the observation post 
overlooking the beautiful South China Sea, some time after his squad has returned after chasing after a low intelligent deserter going AWOL (absent-without-official-leave) named Cacciato, Paul Berlin lets his imagination roam wildly. He imagines the possible march that takes him and his fellow American soldiers through Laos, Burma, India, Afghanistan, Iran, and finally to Paris in France to pursue Cacciato, and perhaps to escape the "bad" Vietnam War. At the same time, flashbacks often bring him back to the painful war experience he endures with his fellow soldiers. Based on a few events of his actual war experience (e.g., the senseless shooting of a water buffalo) and literary devices such as imagery and allusions, O'Brien describes the American soldiers' strong emotions about the war, how they cope with the relentless boredom and terror of a guerilla war, how they treat their enemies and Vietnamese civilians, and finally how they break down morally to even harm their own fellow soldiers and officers. The issues raised by O'Brien in this novel include lack of purpose, the lower standards of the American troops (McNamara's morons), AWOL/desertion, courage or lack thereof, friendly fire, fragging their own officers, and contemptuous attitude toward the Vietnamese, the very people they came to help and protect.

\section{A. A War of No Purpose}

As pointed out by Julie Ooms (2014), the granite of the Vietnam Memorial Wall doesn't have the inspiring engraved text like the Lincoln Memorial and the WWII Memorial. Instead, it comprises of two long, gloomy, black granite walls anchored into the earth and only has the engraved names of the dead soldiers. The Vietnam War was one of no noble purpose. Despite the sacrifice of countless young Americans, it remains a national disappointment and disgrace. Most of the soldiers who were sent to serve in the Vietnam War did not know why they should be there, when their friends, classmates, and comrades were maimed or dying for no reason. It started from the top; even the commanders did not believe in the war they were fighting. In Going After Cacciato, Private First Class (PFC) Paul Berlin describes his first encounter with the leadership of the Americal Division at the Chu Lai's Combat Center on June 3, 1968, “A small, sadfaced corporal in a black cadre helmet waited until they settled down, looking at the recruits as if searching for a lost friend in a crowd. Then the corporal sat down in the sand. He turned away and gazed out to sea. He did not speak. Time passed slowly, ten minutes, twenty, but still the sad-faced corporal did not turn to nod or speak. He simply gazed out at the blue sea... They sat in the bleachers for a full hour. Then at last the corporal sighed and stood up. He checked his wristwatch. Again he searched the rows of new faces. 'All right,' he said softly. 'That completes your first lecture on how to survive this shit. I hope you paid attention"' (O'Brien, 1978, p. 37). No goals of the mission, no encouragement or acknowledgment, no inspiring talks. Just a real warning of how to survive hours of boredom, anxiety, and then terror when it suddenly appears: The grunts are on their own!

When the trainers or commanders do not believe in the honorable purpose of the war, so will the PFCs and Spec 4s. Berlin does not even know where Chu Lai is and he tells his father to look it up in a world atlas. Perhaps at the time when O'Brien was drafted, one of the reasons that commanding officers and noncommissioned officers (NCOs) in Vietnam did not want to be inspiring and to aggressively initiate successful combats because they could incur the risk of being killed by their own men (see Subsection F later on "Fragging"), especially in 1969 and later. Berlin's platoon dislike their commanding officer, Lieutenant (Lt.) Sidney Martin, because he is enthusiastic and idealistic, "No one cared much for Sidney Martin... The way he kept pushing. A believer in mission, a believer in searching tunnels and bunkers. Too disciplined. Too clear headed for such a lousy war" (O’Brien, 1978, p. 105).

Studies have looked at several factors that impact the average American soldiers' perspective about the Vietnam War (The Gale Group, Inc., 2001). A great number of the 2.5 million American soldiers who served in Vietnam came from poor and working class families in inner cities, factory towns, or rural areas. They were barely teenagers who either did not finish high school or just right out of high school. The hot and humid climate in a tropical and impoverished country gave these young Americans their first discomfort and unpleasant environment. Either in a thick jungle or in a muddy rice paddy, they constantly battled against sickness, infection, blood-sucking insects (e.g., leeches, mosquitoes, etc.), and disease-carrying microbes. The nature of the guerrilla war further frustrated these young American soldiers. Hours of boredom of patrolling the countryside or the jungle searching for VCs were mixed with constant fear and anxiety of booby traps, mines, and unseen enemies in potential ambushes. The one-year tour of duty also caused troops to focus on staying alive instead of doing their military duty or winning battles. Misguided military strategies (such as war of attrition $^{1}$, emphasis on body counts ${ }^{2}$, search and destroy missions ${ }^{3}$, free fire zones, etc.) and the resulting, growing hostility of poor Vietnamese villagers toward them did not help. The term "free fire zone" (similar to the policy of "shoot-anything-that-moves," which was considered by General Chuck Yeager during WWII as potentially criminal) was defined during the Vietnam War as "a specific designated area into which any weapon system may fire without any additional coordination with the establishing headquarters" (field Manual FM 6-20) - meaning anyone in this area is considered to be an enemy combatant and can be shot and killed. Toward the end of 1960s, this term was dropped from

\footnotetext{
${ }^{1}$ General William Westmoreland's war of attrition strategy involved escalating military buildup to conduct large-scale "search and destroy" missions, using helicopters and high-tech weapons to find and kill VC and NVA forces. But it was ineffective against the enemy's guerrilla war strategy.

${ }^{2}$ As Ron Ridenhour wrote in 1994: "All gooks were VC when they were dead" [meaning American soldiers can just kill a civilian and count the body as a dead VC]. This strategy encouraged the indiscriminate killing of civilian noncombatants.

${ }^{3}$ The "Search and Destroy" mission was first used ineffectively by the British during the early years of the Malayan Emergency in the late 1940s. This offensive tactic was often used by General William Westmoreland in Vietnam, but it proved ineffective because the US generals underestimated the abilities of the VC and NVA to replace their lost troops and even match or exceed the US forces.
} 
the US military lexicon because this doctrine embraced actions of indiscriminate killing of civilians left in the "free fire zone" that could be considered illegal (Simmons, 1999). All this eventually caused the decline in the morale and performance of American troops in Vietnam. Especially when President Nixon began the "Vietnamization" policy to withdraw combat troops from Vietnam at the beginning of 1969, many American soldiers did not want to die in a war that could not be won.

\section{B. McNamara's Morons and Desertion}

It has been reported that starting in 1966, President Lyndon Johnson and his Defense Secretary Robert McNamara launched the Project 100,000 to lower the military mental standards in order to draft more low-IQ troops for the Vietnam War. These substandard troops were known as "McNamara's Boys," "McNamara Morons," or "the Moron Corps." This project was designed to achieve two objectives. First, President Johnson did not want to send US Reservists and National Guards to Vietnam. Second, US forces did not have to draft many college-educated young men for the Vietnam War; therefore, the administration could avoid alienating middle-class voters. As a result, more than 354,000 of these substandard troops (many of them were disabled men, misfits, and even criminals) were sent into combat in Vietnam, not only to endanger themselves but also their fellow soldiers (Gregory, 2015).

The physical description of Cacciato, the AWOL soldier who is Paul Berlin's friend, indicates that Cacciato is one of the "McNamara's Boys." His appearance and behavior match with someone with Down's syndrome and having mental challenges, "Some of the jokes were about Cacciato. Dumb as a bullet, Stink said. Dumb as a month-old oyster fart, said Harold Murphy," (O'Brien, 1978, p. 2) and "Climbing, he tried to picture Cacciato's face... It's the Mongol influence... See how the eyes slant? Pigeon toes, domed head... Open-faced and naïve and plump, Cacciato lacked the fine detail... that maturity ordinarily marks on boy of seventeen years" (O'Brien, 1978, pp. 7-8). According to the National Institute of Health (NIH, 2018), in addition to some physical disabilities, Down's Syndrome adults also carry some cognitive and behavioral problems such as: language and speech impairment or delay, slow learning, short attention span, poor judgment, and impulsive behavior. Because Cacciato's mental health is not stable, he decides to take off one day on his own to leave the war zone in South Vietnam and walk to Paris, endangering himself and causing his fellow soldiers to risk their lives to rescue him. Another risk that is not mentioned by O'Brien is that Cacciato may not know how to use weapons well or he may not know how to spot enemy's booby or mine traps, representing a disaster in the waiting.

Author Hamilton Gregory, a college graduate and a Vietnam War veteran, personally encountered several of the "McNamara's Boys" during his training in 1967 in Tennessee. He was asked to follow and take care of John Gupton, a young and abnormally thin recruit who did not know how to read, did not know how to write, and could not remember his home address and which state he came from. Gregory remembered vividly his training Captain Bosch's complaint, "Can you believe this idiot was drafted? I tell you who else is an idiot. Fuckin' Robert McNamara. How can he expect us to win a war if we draft these morons" (Gregory, 2015). Even when the training sergeant proposed that Gupton be sent back home because he could not handle the rifle and grenade practice in a safe manner, he was still kept in the army. Another "McNamara's Moron" named Murdoch was sent home just because he was diagnosed later to have schizophrenia. In Going After Cacciato, O’Bien mentions that even the intelligent, West Point-trained Lt. Sidney Martin did cause the gruesome death of his two fellow soldiers by blindly insisting on following the formal Standard Operation Procedure (SOP) of clearing the tunnel, not the informal, more practical field experience. One can imagine how much danger to the troops the less intelligent McNamara's Boys can cause. As presented in 'Tim O'Brien's 'Bad' Vietnam War: In the Lake of the Woods and Its Historical Perspective" (Mahini et al., 2018b, in press), drafted soldiers with criminal records easily became prolific killers of innocent civilians in reported massacres such as Mỹ Lai and Tiger Force.

Desertion during the Vietnam War was quite common in the American Armed Forces, and O'Brien conveys this fact as Cacciato and some of his squad soldiers became deserters. From 1966 to 1972, the number of US soldiers who went AWOL for more than 30 days increased more than four fold, from 15 in 1,000 to 70 in 1,000 (The Gale Group, Inc., 2001). In 1971, Colonel Robert D. Heinl, Jr. wrote that the desertion rates were going up in the Army, Marines, and Air Force. For example, the Army had 65,643 deserters in 1970 and that the rate was more than twice the peak rate for Korea. Desertion can disrupt discipline and destroy morale in troops. Another problem almost as serious than desertion is simply refusal to go to the field or participate in a military operation. The GI simply "just packs his shirt and goes to visit some buddies at another base camp" (Heinl, 1971) because it is more dangerous to wander through the countryside in Vietnam alone (The Gale Group, Inc., 2001).

\section{Disparaging Verbal Abuse of American Troops}

In addition to incompetent personnel in his squad, Paul Berlin must endure the verbal and emotional abuse from many others like lifers or NCOs around him when he first arrives to Vietnam, "Course not, you dumb twerp... Paul Berlin was not a twerp. So it constantly amazed him, and left him feeling much abused, to hear such nonsense-twerp, creepo, butter-brain. It wasn't right. He was a straightforward, honest, decent sort of guy. He was not dumb. He was not small or weak or ugly" (O’Brien, 1978, p. 38). As a result, Paul is dispirited and fearful, "His eyes were down and he climbed the road dumbly... He was dull of mind, blunt of spirit, numb of history..." (O'Brien, 1978, p. 168). This type of rude and derogatory treatment in an immoral, despised war - a war in which a simple walking or patrolling exercise in the booby trap and mine-laden region can mean being killed or being maimed - saps any human dignity left in Paul 
and his fellow soldiers. Consequently, Paul Berlin always walks last in file when his squad is on patrol (O'Brien, 1978, pp. 16, 165). The verbal abuse that Paul Berlin experiences is common for all American recruits, even those collegeeducated ones. In his book McNamara's Folly, author Gregory also reported similar incessant verbal insults he received during his military training: a sad sack of shit, an idiotic turd, all queers, assholes, pansies, pussies, scumbags, slimeballs, shotheads, etc. (Gregory, 2015, p. 21). These insulting words disregard the values of individual soldiers, make them feel weak, and can either enrage them or demoralize them.

There are many reasons that drill instructors, lifers, and commanders used to justify their verbal abuse of recruits and soldiers in the past. First, they wanted to probe and to push the recruits' emotional buttons and to create a stressful situation to see if the soldiers being trained can handle their emotions and retain their "military bearing." A military bearing is defined as "the ability to calmly control [your] reactions to events, even traumatic events" (Thompson, 2002). This ability to handle extreme stress and to think clearly is necessary for survival, especially during a chaotic, deadly combat situation. Second, by exploring the commitment to self-control of the recruits, drill instructors can also explore these soldiers' ability to respect ranks and orders, which is required for the armed forces to function properly and effectively. Finally, drill sergeants can also insult recruits to try to de-individualize them not to think only about themselves. Instead, soldiers should think about their team's goal as a whole and the greater good of the group while being on their military mission (Thompson, 2002). Recently however, it was reported that drill sergeants were told to cut out all the cussing, swearing, insulting, and intimidation of new military recruits. Instead, they were encouraged to adopt a "kinder gentler" role of a mentor, a coach, or a counselor in order to shape young recruits for the future and to retain good soldiers for the Armed Forces. Colonel Jay Chambers, commander of $1^{\text {st }}$ Combat Training Brigade of the $13^{\text {th }}$ Infantry Regiment has reported that the new approach makes a difference because, "The soldiers shoot better, are in better physical condition, and their hearts and heads are in the zone" (Reynolds, 2006). In the past, about one third of recruits dropped out of their enlistments in the first six to twelve months; and many of them cited humiliating treatment as the main reason. This "kinder gentler" approach now helped the Pentagon to achieve their recruiting goals of active duty soldiers for the year by September 30 (Reynolds, 2006).

\section{Courage or the Lack Thereof During the Guerilla War}

In real life O'Brien was drafted at the age of 22, after obtaining his undergraduate degree. In Going After Cacciato, Paul Berlin must be in his late teenage years, just like the average age of the American soldiers (19 years old) during the Vietnam War (The Gale Group, Inc., 2001). Most soldiers in Paul Berlin's platoon do not die from fighting courageously, with honor, or for protection of their fellow comrades in conventional battles. They just die from some foolish reasons or while doing mundane, tedious tasks. Billy Boy Watkins dies from a heart attack - from fear after incurring a minor injury from a mine. Frenchie Tucker and Bernie Lynn get shot in the head during the inspection of an enemy tunnel - while following the "official" military SOP. Lt Sidney Martin is fragged by his own soldiers in a tunnel. Pederson is killed from friendly fire, by the door gunners of the Chinook helicopter that drops the troops off on the field. Rudy Chassler hits a mine. Buff and Ready Mix are shot dead in a small ambush. All these deaths are results of the nature of the guerilla war ${ }^{4}$. Sprinkled throughout his Going After Cacciato novel with vivid and pointed details, O'Brien describes the boring, but highly dangerous life of the American soldiers patrolling the field. Hidden in a complex network of tunnels or in highland dense jungles, NVA and VC practically controlled the time and place of their attacks on the US Armed Forces to avoid the US superior firepower. In an unpleasant climate and disease-laden environment, "they moved through the villages along the muddy Sông Trà Bồng. They cordoned the villages and searched them and sometimes burned them down. They never saw the living enemy. On the odd-numbered afternoons they took snifer fire. On the even-numbered nights they were mortared... (O'Brien, 1978, p. 100). Over the next week they destroyed twelve tunnels. They killed a water buffalo. They burned hootches and shot chickens and trampled paddies and tore up fences and dumped dirt into wells and provoke madness. But they could not drive the enemy into showing himself, and the silence was exhausting... (O'Brien, 1978, p. 105). The men bickered and fought. Caution became skittishness. Irritability became outsight meanness, and worse. They walked with their heads down, stiffy, thinking of land mines and trickery and ambush... (O’Brien, 1978, p. 105). Sidney Martin kept pushing... Inland through Mỹ Khê 1 and 2 and 3 , then south, then southeast, then straight north back to the river. The silence continued and they did not find the enemy" (O'Brien, 1978, p. 106). According to O'Brien in Going After Cacciato, the boredom, the fear, the intense anxiety during these patrols break down the American soldiers' spirit to the point that they fight violently among themselves, with the intention to inflict physical pain on their fellow soldiers. As the mental and physical conditions of the troops become worse, more and more problems arise in their units that further prevent them from being effective.

As a young and inexperienced soldier, the war brings Paul Berlin a lot of fear and terror, "You got an excess of fear biles,' Doc had said one afternoon beneath the tower (O'Brien, 1978, p. 28)... True, he was afraid. Doc was right about that" (O'Brien, 1978, p. 29). Because of his fear, Paul does not want to volunteer to pull out Frenchie Tucker when the latter is shot in the tunnel. To respond to Lt Martin's request of the troops to go down to the tunnel to retrieve Tucker's

\footnotetext{
${ }^{4}$ O'Brien is not correct to infer that the manner of death during the Vietnam War determines the heroism of the soldiers. SP4 Glenn Andreotta was shot in the head while flying his $\mathrm{OH}-6$ helicopter on a recon mission, a death that O'Brien would consider meaningless and call "greased, offed, zapped, etc." But three weeks earlier, Andreotta was a hero jumping into a ditch filled with grime and blood from dead and injured civilians at Mỹ Lai to rescue an eight-year old Vietnamese boy. For his heroic action, he was awarded the prestigious Soldier's Medals posthumously thirty years later (Mahini et al., 2018b - in press).
} 
body, "Berlin stood alone. He felt the walls tight against him. He was careful not to look at anyone” (O'Brien, 1978, p. 90). Even the prospect of receiving a silver medal (which is always in his hope) is not enticing to Paul, who just wants to stay alive. On the patrol trail, Paul "knew he would not fight well. He had no love of mission no love strong enough to make him fight well... Paul Berlin, who had no desire to confront death until he was old and feeble, and who believed firmly that he could not survive a true battle in the mountains..." (O'Brien, 1978, p. 167). Berlin does not want to die. He does not want to fight. He passively follows his squad and hopes to survive his tour. How can he not have fear when NCOs around him mention that he and other soldiers like him are going to die in this hopeless war, "He plodded through the sand, listened while the NCOs talked about the AO [Area of Operations]: 'Real bad shit,' said the youngest of them, a sallow kid without color in his eyes. 'Real tough shit, real bad. I remember this guy Uhlander. Not such a bad dick, but he made the mistake of thinking it wasn't so bad. It's bad. You know what bad is? Bad is evil. Bad is what happened to Uhlander. I don't wanna scare the bejesus out of you-that's not what I want-but, shit, you guys are gonna die" (O'Brien, 1978, p. 39). Some like Benn Nystrom even want to mutilate themselves in order to go home (O'Brien, 1978, p. 106). For Berlin, his fear continues to be overwhelming. When Berlin and his squad finally find Cacciato, they try to capture Cacciato. During this ambush, Berlin fires his automatic rifle uncontrollably out of fear and he eventually wets his pants (O'Brien, 1978, p. 331). O'Brien does not clearly state that in the novel, but it is understood that during a moment of panic, Paul Berlin accidentally shoots and tragically kills his only and best friend Cacciato.

\section{E. Friendly Fire}

O'Brien's literary skills in scrambling the order and the time frame of his stories to invoke the deep empathetic response from his readers plays beautifully in his description of the friendly fire problem in the US Armed Forces. Like a devoted teacher to his students, O'Brien invites his readers to pay special attention to and even to take note of the different events in his stories. At the beginning of Chapter Eleven (Fire in the Hole) of Going After Cacciato, O'Brien mentions Pederson's death, "Pederson was a mess. They wrapped him in his own poncho. Doc Peret found the broken dog tags and slipped them into Pederson's mouth and taped it shut' (O'Brien, 1978, p. 77). Then O'Brien describes the anger and the rage in Pederson's fellow platoon soldiers when their Lt requests white phosphorus to burn down the Hội An (meaning "Peaceful Meeting Place") village, "They watched the village become smoke... Then they began firing. They lined up and fired into the burning village... and the men fired until they were exhausted. The village was a hole... When it was night they began talking about Jim Pederson" (O’Brien, 1978, p. 79). The entire Chapter Eleven makes readers feel like the savage revenge of the Hội An village is justified due to the fact that Pederson is maimed and killed by VC in an ambush or perhaps is blasted off by a mine. Then later in Chapter Twenty (Landing Zone Bravo), readers learn the painful truth, that Pederson is not killed by VC or NVA. He is senselessly and carelessly killed by his own fellow soldiers, the door gunners of the Chinook helicopter that drops the entire platoon soldiers on the ground on that fateful day.

Using repetition after repetition, O'Brien pierces the readers' heart with the continuous, automatic firing bullets to evoke the pain of a pointless war. Normally helicopter door gunners would fire at the treeline during the approach to the landing zone (LZ), while paying extra attention to locations of other nearby choppers (Rottman, 2007). As the Chinook is lowered to unload Paul and his fellow soldiers, its door gunners do not follow the airmobile warfare tactics, which is to cease fire when the infantrymen are about to off-load (Rottman, 2007). Instead, they fire their big machine guns to protect themselves, "The gunners fired and fired. They fired at everything. They were wrapped around their guns... The Chinook touched down softly. The gunners kept firing. They hunched over their hot guns and fired and fired. They fired blindly and without aim... Paul Berlin slipped and went down in the muck... and then lay quietly and watched as the gunners kept firing and firing, automatically, firing and firing. They would not stop. They cradled their white guns and fired and fired and fired... Screaming, the crew chief dragged Pederson to the ramp and threw him out... He'd lost his helmet. Behind him, the gunners strafed the paddies... firing and firing, and Pederson was shot first in the legs. But the gunners did not stop. They fired in sweeping, methodical rows..." (O'Brien, 1978, pp. 130-131). At first, Pederson is calm and does "not go crazy at being shot," but the door gunners keep firing and Pederson is shot again, so hard that "it yanked him backward and he splashed down" (O’Brien, 1978, p. 132). From that point on, Pederson stays calm and decides to revenge against the door gunners. At that time, they still, "kept firing, but Pederson took his time... He squeezed of a single shot... The sound was different-hard and sharp and emphatic and pointed. He fired again, then again... The gunners went berserk with their firing but Pederson took great care, aiming and firing... Bobbing in the slime, he tracked the Chinook and fired into its great underside... he was composed and entirely within himself. Suddenly the door gunners were gone, but still the hot guns kept swiveling and firing, automatically..." (O'Brien, 1978, p. 132). Through this scene, O'Brien emphasizes that not all casualties at war are due to combat. Friendly fires can traumatize the troops greatly. It has been reported that, "The conditions and quality of the American effort by this time [during the "bad" Vietnam war period] are more than evidenced by one statistic. Thirty percent of all the casualties during this period came from friendly fire" (Hochgesang, Lawyer, and Stevenson, 1999).

Then to add to the readers' exasperating feelings about the friendly fire on Pederson, on Page 143 of Chapter 22 (Who They Were or Claimed to Be), O'Brien describes how great of a person Pederson is. He would bow to poor villagers, talk to them in Vietnamese, and show them his church picture (although he is not Catholic) to express some solidarity with the Catholic villagers. Doc said that Pederson "had a Moral Stance," because he once "stopped the Third 
Squad from burning down a village in Pinkville" and he even "gave first aid to a dying VC woman" (O'Brien, 1978, p. 142). Pederson also spends time writing to the parents of his fallen fellow soldiers, without expecting anything in return. It is tragic that the life of a beautiful human being like Pederson is wasted in a friendly fire as he is senselessly killed by his own fellow soldiers. Looking back to Chapter Twenty when Pederson is described to be calmly taking down the Chinook door gunners while being badly injured, perhaps knowing that he would be dying, Pederson tries to take down the coward door gunners to prevent another tragedy and to save his fellow soldiers' lives in the future. In these enthralling chapters, O'Brien is successful in convincing us emotionally that war is cruel and never needed. Ironically, online literary review websites do not readily see the obvious "friendly fire" issue for Pederson. For Chapter 20 of Going After Cacciato, litcharts.com reports the following summary and analysis, "As the helicopter drifts to the ground, the soldiers open fire, though the narrator doesn't say at whom, exactly, they're firing. The helicopter touches down, and the soldiers rush out, still shooting into the distance... The ambiguity in O'Brien's description of the helicopter's landing is a good encapsulation of the Vietnam War itself. It's often been said that in Vietnam, the American soldiers didn't properly understand just who they were fighting, or what they were fighting for" ("litcharts.com," 2018). The summary of O'Brien's novel on the litcharts.com website also mentions that Lt Sidney Martin was "presumably murdered by Johnson," but the means of murdering or "fragging" was not mentioned. O'Brien has said in author interviews that any soldier in their platoon, except Cacciato, could frag their commander.

\section{F. Fragging}

After witnessing a couple of traumatic events (e.g., the senseless killing of the innocent water buffalo as a scapegoat by Stink [O'Brien, 1978, p. 50], the careless shooting/killing of Pederson - the most moral person in the squad - by their own helicopter door gunners, Pederson's revenge [O'Brien, 1978, pp. 77, 131-132], and participating in the burning and obliteration of the village Hội An [O’Brien, 1978, pp. 78-79]), Paul Berlin eventually steps unwittingly into the most sinful act of an American soldier during the Vietnam War: the "fragging" (murder with a fragmentation grenade) of their own officers or soldiers. In Going After Cacciato, O’Brien does not openly describe the details of the killing, or fragging, of West Point graduate Lt Sidney Martin. This is only understood if readers have some knowledge about fragging (Lepre, 2011). Even after the deaths of Frenchie Tucker and Bernie Lynn for strictly following the military SOP for searching the tunnels, Lt Sidney Martin still insisted that the tunnels be carefully searched before his troops could drop in grenades. At that time, "it was there, high in Lake Country, that Oscar Johnson began talking seriously about solutions (O'Brien, 1978, p. 178). To get the rest of the platoon's support of his plan of fragging Lt Martin, Oscar told others, "'Everybody has to touch it,' was what Oscar Johnson had said... 'And it's for your own damn good, and even if you don't join in, even so, it'll happen any way, but, look, it's for our own good.' So he'd pressed the grenade against Cacciato's limp hand... Was it touching? Was it volition? May be so, maybe not. 'That's everybody,' Oscar said afterward. And then Lieutenant Corson came to replace Lieutenant Sidney Martin. The way events led to events, and the way they got out of human control. 'A sad thing,' Cacciato had said on the day afterward... A very sad thing. Cacciato was dumb, but he was right. What happened to Lieutenant Sidney Martin was a very sad thing” (O’Brien, 1978, p. 247). Perhaps the troops must chase after Cacciato when he left AWOL because Cacciato knew and disapproved of their murder of Lt Sidney Martin. Cacciato was also right because fragging represents the lowest morality of America. The lack of remorse in Paul Berlin and his fellow soldiers is extremely sad. Even sadder of all was the fact that Lt Martin truly cared about the soldiers under his command, "he did not enjoy battles. Neither bloodthirsty nor bloodshy... But battles had to be fought... Though they did not know it, and never would, he loved these men... he loved them all"' (O’Brien, 1978, p. 165).

The term "fragging" was coined during the Vietnam War because this type of murder was named after the murderers' weapon of choice: the standard fragmentation hand grenade M26, M61 or M67. Unlike rifles and pistols, grenades were not assigned to individual soldiers by serial number, and once exploded, they left no traceable ballistic evidence that may be used to identify the perpetrator (Brush, 2010). Grenades were also effective in maiming and killing the victims when they were dropped into the sleeping bunkers or tents at the middle of the night. The Pentagon had always been reluctant to publicly discuss and address the fragging problem in the military. Democratic Majority Leader Senator Mike Mansfield of Montana was the first member of the Congress to raise the fragging issue on the floor of the Senate on April 20, 1971. In an emotionally trembling voice, Mansfield described the painful details about the death of $1 \mathrm{st} \mathrm{Lt}$ Thomas A. Dellwo, of Choteau, Montana, "He was not a victim of combat. He was not a casualty of a helicopter crash or a jeep accident. In the early morning hours of March 15, the 1st Lt from Montana was 'fragged' to death as he lay sleeping in his billet at Biên Hòa (meaning "Recorded Peace"). He was murdered by a fellow serviceman, an American GI. 'Fragging' so I have been advised by the Secretary of the Army, refers to the use of a fragmentation grenade in other than a combat situation by one person against another to kill or do bodily harm." The death of Dellwo, a 24-yearold West Point graduate who wanted to be a career soldier, was especially tragic and senseless because he was not even the intended victim. His murder occurred just four weeks before his scheduled return to the US (Brush, 2010).

In the brief comments following Mansfield's disclosure, Republican Senator Charles Mathias of Maryland noted that Mansfield had made history because "he has surfaced the word 'fragging' for the first time on the Senate floor." Mathias also succinctly captured the dismay and emotional pain of those present that day: "In every war a new vocabulary springs up... but in all the lexicon of war there is not a more tragic word than 'fragging' with all that it implies of total failure of discipline and depression of morale, the complete sense of frustration and confusion and the 
loss of goals and hope itself' (Brush, 2010). During the period of troop withdraw period from 1969 to 1973 , fragging incidences increased significantly in the military, to the point that by 1971, U.S. Army Colonel Heinl, Jr. declared in the Armed Forces Journal that "The morale, discipline, and battleworthiness of the U.S. Armed Forces are, with a few salient exceptions, lower and worse than at any time in this century and possibly in the history of the United States. By every conceivable indicator, our army that now remains in Vietnam is in a state approaching collapse, with individual units avoiding or having refused combat, murdering their officers and non commissioned officers, drug-ridden, and dispirited where not near mutinous" (Heinl, 1971). Colonel Heinl also raises the issue of "fragging" in the military as a reflection of the decline in the societal morale in the US as a whole, "It is a truism that national armies closely reflect societies from which they have been raised. It would be strange indeed if the Armed Forces did not today mirror the agonizing divisions and social traumas of American society, and of course they do... At best count, there appear to be some 144 underground newspapers published on or aimed at U.S. military bases in this country and overseas... These journals are not mere gripe-sheets that poke soldier fun in the 'Beetle Bailey' tradition, at the brass and the sergeants. 'In Vietnam,' writes the Ft Lewis-McChord Free Press, 'the Lifers, the Brass, are the true Enemy, not the enemy.' Another American West Coast sheet advises readers: 'Don't desert. Go to Vietnam and kill your commanding officer'.' By 1971, it was reported that fragging in the Americal Division was at a frightening level of about once per week (Heinl, 1971).

It is truly sad that military casualties were not limited to combat operations and that intelligent and promising higher rank officers were killed or maimed by their own rogue soldiers, sometimes over trivial issues such as being scolded for drug use or sleeping while guarding, etc. (Lepre, 2010). Most of the fragging incidents in Vietnam went unresolved at the time they happened. In addition, discharged GIs during the Vietnam era could not be charged with crime they committed oversea because the 1955 Supreme Court's Toth v. Quarles case denied the armed services the power to put veterans under trial under military law. Congress took no action for more than 40 years after the Vietnam War ended, although they had the authority to provide civilian venues for these cases. The 2000 Military Extraterritorial Jurisdiction Act (which allows federal district court trials for veterans accused of committing serious crimes during their overseas service) came too late for the unresolved Vietnam-era fragging cases because the Constitution prohibits Congress from enacting ex post facto laws. Even if the killers who managed to avoid detection by the military at the time of their crimes confess or are accused now, they cannot be prosecuted. Thus, many fragging cases will remain forever unresolved (Texas Tech University Press, 2011) and justice could not be achieved for the unfortunate victims of fragging in Vietnam. One may also ask, "If a life of an intelligent or West Point-educated American officer is not important to some [criminal] American soldiers, how much a life of a "gook" or a "dink" is worth to them?" As a result, indiscriminate raping, or killing of innocent civilians became possible and just a logical next step.

\section{G. Disparagingly Contemptuous to Vietnamese}

During the Vietnam War, the Military Assistance Command, Vietnam (MACV) issued the "Nine Rules" Pocket Card for all American soldiers to guide their behavior and conduct. For example, Rule 1 states, "Remember we are guests here. We make no demands and seek no special treatment;" Rule 2, "Join with the people! Understand their life, use phrases from their language and honor their customs and laws;" Rule 3, "Treat women with politeness and respect;" Rule 5, "Always give the Vietnamese the right of way..." and Rule 9, "Above all else you are members of the U.S. Military Forces on a difficult mission... Reflect honor upon yourself and the United States of America" (MACV, 1967). But what O'Brien's American soldiers did in Going After Cacciato, to the contrary, is to use the offensive, disparaging, and contemptuous language toward the Vietnamese, "At night they wailed. Coyotes, Eddie laughed. Stink Harris did not laugh. Dinks, he muttered: Dinks from Dinksville, Damsels from Gooktown. Silent through the sunny days, the old women howled endlessly through the night" (O'Brien, 1978, p. 60). The words "dinks" and "gook" are derogatory terms that were originally and predominantly used by the U.S. military during wartime, especially during the Korean and Vietnam Wars to address Asian people.

It has been reported that many military trainers wanted US troops to use these contemptuous words to dehumanize the Vietnamese, as Ron Ridenhour (who helped expose the 1968 Mỹ Lai Massacre) wrote, "I first came face to face with my own intimate knowledge of gooks in Vietnam. First time I heard the word was on the way to Vietnam. 'When you get to Vietnam,' one of my first drill sergeants said, 'you'll have one job. Killing gooks [meaning VC?].' Seemed straightforward enough. By the time I got to Vietnam, just before Christmas 1967, everydamnbody was talking about killing gooks. Gooks this, gooks that. The gooks, the gooks, the gooks. At first there was some confusion. How did you tell gooks from the good Vietnamese, for instance? After a while it became clear. You didn't have to. All gooks were VC when they were dead [one can just kill a civilian as a VC]" (Ridenhour, 1994). Ron Haeberle, who photographed the horrific 1968 Mỹ Lai Massacre, recalls the message imparted to so many soldiers before their arrival in Vietnam: "We were told, 'Life is meaningless to these people"... leaving unspoken the rest of that sentiment: The enemy is not like us. They're not quite human" (Theiss, 2018). Professor Howard Jones reported that General Westmoreland of the Americal Division had said, "Life is plentiful, life is cheap in the Orient," and so "the U.S. military seemed to take that to heart in prosecuting a brutal war of attrition" (Montgomery, 2018). All of this is due to ignorance of the local Vietnamese people, as O’Brien once wrote, "My time in Vietnam is a memory of ignorance and I mean utter ignorance. I didn't know the language... I knew nothing about the culture of Vietnam. I knew nothing about the religion, religions. I knew nothing about the village community. I knew nothing about the aims of the people, whether they were for the 
war or against the war... The final effect was of a moron wandering through a foreign land, or a blind man wandering through a foreign land" (Klein, 2004).

O'Brien is right thinking that it was not helpful that he did not know about the culture and even the history of Vietnam during his tour. He and most American soldiers do not know that Vietnam has more than 4,000 years of recorded history; during this time they were dominated by the Chinese for a total of 1,100 years and were under the French control for another 100 years. To preserve their existence as an independent nation, the Vietnamese people had to constantly fight against the repeated Chinese invasions and efforts to erase their culture. Vietnam was also one of the few small Asian countries in the world that defeated the invincible Mongol warriors, not only once, but three times. Vietnam even had elephant-riding warrior princesses (Hai Bà Trưng [or the Two Trưng Sisters] and Bà Triệu [or the 19-year old Warrior/Lady Triệu]) who won battles for independence against the Chinese invaders more than 1,300 years before the French heroine Jeanne d'Arc. The Gale Research (2002) published the following text about the Two Trưng Sisters in www.encyclopedia.com: "For 12 years, the United States fought a bloody guerilla war against Vietnam. Although America was many times richer and had far superior military might, Vietnam prevailed in the end... It was not the first war of resistance to be fought by the Vietnamese people, nor would it be the last. The revolutionary spirit is a Vietnamese tradition that dates back many hundred years, launched by two heroic women in the $1^{\text {st }}$ century CE. The story of the Trung sisters, who led Vietnam's very first war of resistance, is the story of Vietnam itself' (Gale Research, 2002). As such, thinking that the people they come to protect are subhuman/pitiful and being ignorant of their culture are ones of the biggest mistakes made by the US Armed Forces. As a result, American soldiers felt isolated, resentful, and insolent. Some even committed abusive violence ${ }^{5}$ to further drive Vietnamese civilians away.

Not only Paul Berlin and his fellow soldiers do not like the Vietnamese people and their complex language, everything about the physical country of Vietnam invokes reprehensible feelings on all his senses. To Berlin, the war is very wet (O'Brien, 1978, p. 7); the wetness that causes fungus to grow and makes their skin brittle. The smell of the war is the smell of the latrine (O'Brien, 1978, p. 41). In addition to the horrid stench on the battlefields, "his clothes would begin to smell of the country, the mud and algae and manure and chlorophyll and decay and mildew" (O'Brien, 1978, p. 210). Even when "the beaches were clean, white, beautiful..." (O'Brien, 1978, p. 254) "the sand of the ocean smells like sour milk, the clean air near the water smells like mildew" (O’Brien, 1978, p. 39).

As a respected Vietnam War author decades later, O'Brien still does not care much about the Vietnamese language and culture. He does not bother to spend any tiny amount time to check with Vietnamese-speaking people in the US to know that "Sarkin Aung Wan" is neither a Chinese nor a Vietnamese name (Vietnamese letters do not have a "W", perhaps "Quan" or "Quân" or "Quãn" is possible), and that "Li" and "Hgoc" are not Vietnamese spellings (Christopher, 1995; as cited by Heberle, 2001, p. 134). Perhaps by “Li," O’Brien means "Lý" (meaning "Lion”) and by "Hgoc," he means "Ngọc" (meaning "Gemstone or Pearl"). O’Brien also does not know that Sarkin would not wear "áo dài” when escaping as a refugee. "Áo dài," meaning long and flowing tunic with side slits from the waist down, is worn with pants made of soft materials, not with a dress or a skirt underneath. "Áo dài” is worn only for attending high school or college, at formal work place, or at formal function, not for daily and normal activities. O’Brien does not know that Chợ Lớn (a large Chinatown next to Sài Gòn) would not be a combat zone, that VC would not dare to execute people in the city earlier than 1968, or that old people would not "howl" due to the loss of material possession like a water buffalo, or that "Nguyễn" is a last name and not to be used to name an animal, or that "Xã" does not mean "soil" or "home" (only "community"), etc. Because of the difficulty in learning the language to communicate, Paul's fellow soldiers resort to firing guns to impose on Vietnamese people, "This was too much for Stink Harris. Enraged, he'd throw away the dictionary and rattle off a whole magazine of ammunition... Dinkese... 'May be the dinks got things mixed up... may be the gooks cry when they are happy"' (O’Brien, 1978, p. 261-262). Without trying to obtain understanding and trust from Vietnamese villagers, these American soldiers feel more unappreciated, isolated, and outraged. Not knowing the language, they do not know whom to trust (O'Brien, 1978, p. 261), and they cannot tell the difference between good and evil in their action. The carelessness of O'Brien while writing this novel proves it well.

But some American veterans did have some deep reflections about their service time during the war and their past treatment of the local Vietnamese, "My feelings about the civilian population bordered on venomous. Not only did I feel superior to them, the burning hatred in their eyes scared me. Soon after my arrival in Vietnam the truth was obvious. Even the South Vietnamese civilians hated Gl's and the American Army. We'd bombed their cities, villages and country flat. We killed, wounded and maimed members of their families and raped their culture. I often wondered how I would feel toward them if they had invaded the US and done to our country what we'd done to theirs. We invaded their land and took control of it and for years there was an army of 500,000 twenty year old fighters, armed to the teeth, in a bad mood, roaming all over their country... This may seem strange to say but I definitely am more tolerant of other races, religions and ideologies because of my time in Vietnam. I saw first hand that all people are the same. They all need and want the same things and will definitely kill other humans to defend their homes, families and interests. Culture, religion, ideas and theories may be different but none of that makes any difference anyway. All that counts is love of family, loyalty to quality behavior and protection of individual rights and freedoms. All people, American or Vietnamese, react the same to these simple truths. While I was in Vietnam I definitely 'did not' see the quality in tolerant behavior and respect for other cultures, just the opposite. What I learned then was 'might is right' and whoever

\footnotetext{
5 "Abusive Violence" is a term used by Laufer et al. (1984) in "War Stress and Trauma: The Vietnam Veteran Experience"
} 
could bring the most fire power to bear was the superior race... The lesson I carried for the rest of my life is never, never underestimate any other human being. No matter how small, ignorant or uneducated they are, they are all capable of magnificent feats of sacrifice, bravery and indescribable violence" (Hochgesang, Lawyer, and Stevenson, 1999).

\section{CONCLUSIONS}

Like it or not, O'Brien is a Vietnam War novelist because he adroitly paints the complete war picture in his military life and the life of other American soldiers during this part of the US history. In his novels, O'Brien uses diverse settings, vivid imaginary, and repetition to illustrate the American perspectives during this unpopular war. The troops' issues raised by O'Brien in Going After Cacciato include lack of purpose, lower standards of drafted troops, desertion/AWOL, lack of courage in a guerrilla war, friendly fire, fragging higher-ranked officers, and contemptuous attitude toward Vietnamese, the very people they claim to help and protect. At the same time, O'Brien also examines the psychological effects on American soldiers during this immoral and senseless war - one that represents a period of impotence in the psyche of the US, as the most powerful nation in the world lost the war in a small and poor Third World country. That was because "in the wry words of Pogo - we have met the enemy, and they are us" (Heinl, 1971). The only silver lining in Going After Cacciato is the fact that we still have soldiers with deep conscience and high "moral stance" such as Pederson. Even a Down Syndrome-afflicted soldier like Cacciato still has the moral courage and kindness not to participate in the fragging crime of his commanding officer. These uncompromising values and qualities are what keep America, despite its past mistakes, one of the top countries in the free world.

\section{REFERENCES}

[1] Ackerman, E. (2017). Tim O’Brien on What We All Can Learn from Ken Burns' 'The Vietnam War.' The Daily Beast.com, September 24. https://www.thedailybeast.com/tim-obrien-on-what-we-all-can-learn-from-ken-burns-the-vietnam-war (accessed 30/3/2018).

[2] Brush, P. (2010). The Hard Truth About Fragging. 28 July. http://www.historynet.com/the-hard-truth-about-fragging.htm (accessed 30/3/2018).

[3] Gale Research Inc. (2002). Trung Sisters (D. 43 CE) Women in Word History: A Biographical Encyclopedia. https://www.encyclopedia.com/women/encyclopedias-almanacs-transcripts-and-maps/trung-sisters-d-43-ce (Accessed $8 / 14 / 2018)$.

[4] Gregory, H. (2015). McNamara's Folly. The Use of Low-IQ Troops in the Vietnam War Plus the Induction of Unfit Men, Criminals, and Misfits. Infinity Publishing, PA.

[5] Heberle, M. A. (2001). A Trauma Artist - Tim O'Brien and the Fiction of VIETNAM. University of Iowa Press, Iowa City.

[6] Heinl, Jr., Col. R. D. (1971). "The Collapse of the Armed Forces." Armed Forces Journal, 7 June. https://msuweb.montclair.edu/ furrg/Vietnam/heinl.html (accessed 30/3/2018).

[7] Hicks, P. (2005). A Conversation with Tim O’Brien. Indiana Review: 27 (2), pp. 85-95.

[8] Hochgesang, J., T. Lawyer, and T. Stevenson. (1999). The Psychological Effects of the Vietnam War. Ethics of Development in a Global Environment. https://web.stanford.edu/class/e297c/war_peace/media/hpsych.html (accessed 21/3/2018).

[9] Kent, A. (2015). The Most Expensive Wars in U.S. History. May 21. https://247wallst.com/special-report/2015/05/21/themost-expensive-wars-in-u-s-history/ (accessed 4/4/2018).

[10] Klein, N. (2004). Bring Najaf to New York. August 26. https://www.thenation.com/article/bring-najaf-new-york/ (accessed 4/4/2018).

[11] Laufer, R. S., M.S. Gallops, and E. Frey-Wouters. (1984). War Stress and Trauma: The Vietnam Veteran Experience. Journal of Health and Social Behavior: 25 (1), pp. 65-85.

[12] Lepre, G. (2011). Fragging: Why U.S. Soldiers Assaulted their Officers in Vietnam. Lubbock: Texas Tech University Press, TX.

[13] Litcharts.com. (2018). Going After Cacciato Chapter 20 - Summary and Analysis. https://www.litcharts.com/lit/going-aftercacciato/chapter-20 (accessed 16.6.201).

[14] Mahini, R. N-T., E. Barth, and J. Morrow. (2018a). Tim O’Brien's 'Bad' Vietnam War: The Things They Carried and Its Historical Perspective. Theory and Practice in Language Studies, Volume 8, Issue 10, pp. 1283-1293. October.

[15] Mahini, R. N-T., E. Barth, and J. Morrow. (2018b). Tim O’Brien's 'Bad' Vietnam War: In the Lake of the Woods and Its Historical Perspective. Theory and Practice in Language Studies, Volume 8, Issue 12, December (in press).

[16] Military Assistance Command, Vietnam (MACV) (1967). Pocket Card, "Nine Rules." September. Scanned by University of Missouri - Kansas City. http://law2.umkc.edu/faculty/projects/ftrials/mylai/Myl_wmac.htm (accessed 4/4/2018).

[17] Montgomery, N. (2018). My Lai: 'A stain on the Army.' Stars and Stripes. https://www.stripes.com/news/special-reports/1968stories/vietnam-at-50-my-lai-a-stain-on-the-army-1.516502 (accessed 1/4/2018).

[18] National Institute of Health (NIH) (2018). What are the common symptoms of Down syndrome. https://www.nichd.nih.gov/health/topics/down/conditioninfo/symptoms (accessed 30/3/2018).

[19] O’Brien, T. (1978). Going After Cacciato. Broadway Book, Random House, Inc. New York.

[20] O’Brien, T. (1990). The Things They Carried. Houghton Mifflin Harcourt Publishing Company. New York.

[21] O'Brien, T. (1994). In the Lake of the Woods. Penguin Books Ltd, New York.

[22] Ooms, J. (2014). "Battles are always fought among human beings, not purposes": Tim O'Brien's fiction as a response to the crisis of modernity. Renascence 66 (1), January. https://www.highbeam.com/doc/1G1-364957531.html (accessed 30/3/2018).

[23] Ridenhour, R. (1994). Jesus Was a Gook. The Vietnam Generation Big Book, Volume 5, Number 1-4. March. http://www2.iath.virginia.edu/sixties/HTML_docs/Texts/Narrative/Ridenhour_Jesus_01.html (accessed 30/3/2018). 
[24] Reynolds, D. (2006). Drill Sergeants: No More Mr. Mean Guy. ABC News. October 11. https://abcnews.go.com/US/story?id=2555758\&page=1 (accessed 14/6/2018).

[25] Rottman, G.L. (2007). Vietnamese Airmobile Warfare Tactics. Osprey Publishing, Great Britain.

[26] Simmons, L.M. (1999). Free Fire Zones. In: Crimes of War: What the Public Should Know, Roy Gutman, Ed., July, https://web.archive.org/web/20050924182430/http://www.crimesofwar.org/thebook/free-fire-zones.html (accessed 8/07/2018), W. W. Norton \& Company.

[27] Slay, Jr., J. (1999). A Rumor of War: Another Look at the Observation Post in Tim O’Brien's Going After Cacciato. Critique, Volune 41, Issue 1, pp. 79-85. Fall. https://www.tandfonline.com/doi/abs/10.1080/00111619909601579 (accessed 4/4/2018).

[28] Texas Tech University Press (2011). New Release. Military historian examines Vietnam era fragging cases - including details of many that may never be resolved. 16 May. http://tupress.org/docs/9780896727151PressRelease.pdf (accessed 30/3/2018).

[29] The Gale Group Inc. (2001). The American Soldier In Vietnam. Vietnam War Reference Library. https://www.encyclopedia.com/history/encyclopedias-almanacs-transcripts-and-maps/american-soldier-vietnam (accessed $1 / 4 / 2018)$.

[30] Theiss, E. (2018). The Photographer Who Showed the World What Really Happened at My Lai. Time Magazine. http://time.com/longform/my-lai-massacre-ron-haeberle-photographs/ (accessed 23/4/2018).

[31] Thompson, P. (2002). The Real Insider's Guide to Military Basic Training: A Recruit's Guide of Important Secrets and Hints to Successfully Complete Boot Camp. Universal Publishers/uPUBLISH.com.

[32] Vernon, A. and C. Calloway (2010). Approaches to Teaching the Works of Tim O'Brien. Vernon, A. and C. Calloway (Editors). The Modern Language Association of America. New York. First Edition.

[33] Walzer, J.B. (2010). Literature and the Vietnam War. Dissent Magazine. Summer. https://www.dissentmagazine.org/article/literature-and-the-vietnam-war (accessed 4/4/2018).

[34] Womack, A.-M. (2013). "Just a creature of his own making": Metafiction, Identification, and Gender in Going After Cacciato. MFS Modern Fiction Studies, Volume 59, Issue 4, pp. 811-832. December. https://www.researchgate.net/publication/265974090_Just_a_Creature_of_His_Own_Making_Metafiction_Identification_and_ Gender_in_Going_after_Cacciato (accessed 4/4/2018).

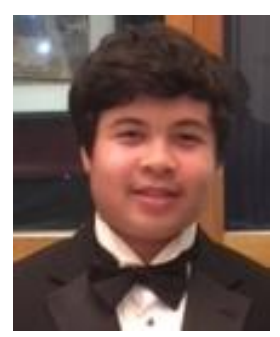

Noor (meaning Light) Mahini (full name Ramtin Noor-Tehrani Mahini) was born in October 2001 in Berkeley, CA and is currently a junior at Acalanes High School in Lafayette, CA, USA. Noor has been a highachieving student since middle school, excelling in computers, math, and science. He applies his deep critical thinking in most things he does, especially in writing English essays and in conducting a small climate change research project awarded by the Acalanes Parents Club at school. Raised by first-generation immigrant parents (Ramtin T. and Xuannga, who received PhD/engineering and MPH/toxicology, respectively, from University of California, Berkeley), Noor's life purpose is to develop a morally respectable character and to become a responsible, devoted citizen to his people/his country and an advocate for human rights.

Noor is a third degree black belt in Tae Kwon Do and enjoys tennis and golf. He is currently doing longterm volunteer work at Youth Tennis Advantage (YTA) to assist children with academics and tennis. Although he loves piano, he is better in viola as he has been playing viola in school orchestras for 5 years. Regardless of what his future college major and career aspiration may be, his life goal is to help make this world a better place.

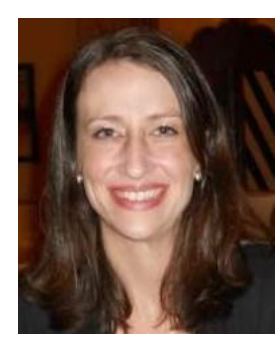

Erin Barth received her Bachelor's and Master's degrees as well as her teaching credential from University of California, Davis, USA.

She is currently an English teacher at Acalanes High School in Lafayette, CA. She lives with her husband Ben, daughter Madeline, and their two Boxers Fletcher and Calvin.

Mrs. Barth enjoys going the extra mile for her students. She is always willing to spend time after school in order to help her students improve their writing skills and develop their appreciation for literature.

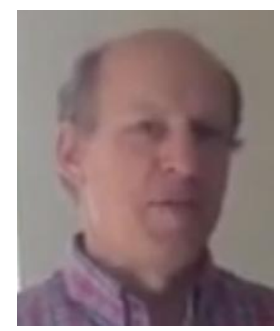

Jed Morrow, being a son of an American WWII veteran, has natural curiosity, special interest, and in-depth knowledge about wars. He lives with his family in the San Francisco Bay Area.

He is currently an AP US History teacher at Acalanes High School in Lafayette, CA. He always challenges his students' critical thinking capability by enthusiastically sharing rare primary source documents with them.

In addition to academic teaching, Mr. Morrow stays physically active by being a great sport coach admired by his students, especially track and field and cross country. 